\title{
Reduced bronchial CD4+ T-cell density in smokers with occupational asthma
}

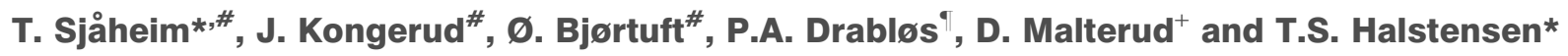

ABSTRACT: Cigarette smoking may alter bronchial inflammation in asthma. Multicolour immunohistofluorescent examination on bronchial cryosections was used to examine bronchial inflammatory cell infiltrate in patients with occupational asthma. Monoclonal antibodies to CD3, $C D 4, C D 8, T-c e l l$ receptor- $\delta 1, C D 68$ and human leukocyte antigen-DR were combined to identify Tcell subsets and macrophages in bronchial biopsies from 20 workers with occupational asthma (12 smokers and eight nonsmokers), 15 healthy workers (seven smokers and eight nonsmokers) and 10 nonsmoking, nonexposed controls.

The increased subepithelial CD4+ T-cell density in nonsmoking asthmatics was not present in smoking asthmatics, who had the lowest CD4+ T-cell density of all groups. The decreased subepithelial CD4+ and CD8+ T-cell density correlated with a reduction in lung function, as measured by percentage predicted forced expiratory volume in one second, in smoking asthmatics only. Although smoking asthmatics had a significantly increased number of intraepithelial CD8+ T-cells and macrophages compared with nonsmoking asthmatics, the proportion of $\gamma \delta$-T-cells was significantly decreased in both asthmatic groups.

Smoking asthmatics had a distinctly different distribution of T-cell subsets compared with nonsmoking asthmatics. The accumulation of subepithelial CD4+ T-cells, which was observed in nonsmoking asthmatics, appeared to be inhibited in smoking asthmatics, suggesting a smokinginduced bronchial immune modulation, at least in occupational asthma in the aluminium industry.

\section{KEYWORDS: Asthma, inflammation, smoking, T-lymphocyte subsets}

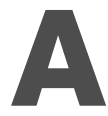
sthmatic airway inflammation has mostly been examined in atopic, nonsmoking subjects, where the increased bronchial density of CD4+ T-cells appears central [1, 2]. Although nonatopic and occupational asthma seem to have different immunopathological mechanisms from atopic asthma, mucosal T-cells are prominent in all conditions [3-5]. Little is known regarding the influence of smoking on the bronchial inflammatory response in asthma. Only few data are available on airway pathology in smoking asthmatics, as reviewed by THOMSON et al. [6]. The main findings are reduced eosinophils in both induced sputum and peripheral blood, while neutrophils are increased in induced sputum samples.

Bronchial biopsy studies in smoking asthmatics are lacking, apart from the current authors' previous study of occupational nonatopic asthma in aluminium potroom workers [7], who were exposed to a complex mixture of particulates and gases [8]. Even though smoking and nonsmoking asthmatics had parallel increases in reticular basement membrane thickness, the smoking asthmatics had no increase in subepithelial total leukocyte density (CD45+ cells). This was in contrast to the nonsmoking asthmatics, who had increased total leukocyte density and displayed similar mucosal-airway inflammation as previously shown in "traditional", nonoccupational asthma [1]. Accordingly, the aim of the present study was to examine bronchial T-cell subsets and macrophages in smokers and nonsmokers with occupational asthma. Multicolour immunohistofluorescence staining was performed to identify macrophages and T-lymphocyte subsets (CD3+, CD4+, CD8+, $\gamma \delta$-T-cells) in bronchial biopsies. The results revealed that the increase in subepithelial CD4+ T-cells found in nonsmoking asthmatics was not observed in smoking asthmatics.

\section{METHODS \\ Subjects}

Potroom workers in aluminium smelters with occupational asthma $(n=20$; eight nonsmokers and 12 smokers) were included in the present study. The controls consisted of 15 healthy potroom workers (eight nonsmokers and seven smokers) and 10 healthy, nonexposed subjects (all nonsmokers). The diagnosis of occupational
AFFILIATIONS

*Laboratory for Mucosal Immunology (LMI), Dept of Oral Biology, University of Oslo,

\#Dept of Respiratory Medicine, Rikshospitalet, Oslo,

"Health Dept, Hydro Aluminium Karmøy, Håvik, and

+Health Dept, Elkem Aluminium Lista, Farsund, Norway.

CORRESPONDENCE

T. Sjåheim

Rikshospitalet

0027 Oslo

Norway

Fax: 4723073917

E-mail: tonebs@odont.uio.no

Received:

March 072006

Accepted after revision:

July 262006

SUPPORT STATEMENT

The study was supported by the University of Oslo, the Norwegian Research Council and the Nordic Aluminium Industry's Secretariat for Health, Environment and Safety (AMS).

European Respiratory Journal Print ISSN 0903-1936 Online ISSN 1399-3003 
asthma was set by confirming the diagnosis of bronchial asthma according to international guidelines [9] and by establishing a causal link between asthma and the working environment, in line with previously defined criteria for occupational asthma in the aluminium industry [10]. Serial monitoring of peak expiratory flow was performed both at work and away from work. The inclusion criteria were: initially asymptomatic exposure period (latency); symptoms of airway obstruction (i.e. dyspnoea, wheezing and cough), usually occurring several hours after exposure or during sleep; and improvement of the symptoms after absence from work for several days or longer. Reversible airway obstruction, defined as $>15 \%$ increase in forced expiratory volume in one second (FEV1) after inhalation of $\beta_{2}$-agonist and diurnal peak expiratory flow variability $>15 \%$, was documented in all asthmatic subjects. All patients with suspected work aggravation of underlying asthma or a history of allergy or childhood asthma were excluded. Characteristics of the study population are described in table 1 and further detailed elsewhere [7]. Half of the asthmatics (three out of eight of the nonsmokers and seven out of 12 of the smokers) had been relocated to nonpolluted working environments. Ex-smokers (who had ceased smoking $>1$ yr previously) and never-smokers were all classified as nonsmokers. Two of the asthmatics and three of the healthy workers were ex-smokers. Median smoking load was 13 pack-yrs (range 8-31) for the asthmatics and 17 packyrs (range 13-32) for the healthy workers. None of the participants had a history of allergy, familial asthma or childhood asthma and their total immunoglobulin (Ig)E levels were within the normal range. The controls had no symptoms from upper or lower airways. Two of the asthmatic subjects were females (one nonsmoker and one smoker), whereas the rest of the participants were males. The study was approved by the Regional Ethics Committee and written informed consent was obtained from all subjects.

Spirometry and flexible bronchoscopy were performed in accordance with international guidelines as previously described [7]. Bronchial biopsies (maximum six from each subject) were taken from the second- and third-generation carina of the right lung and processed for cryosectioning (snap frozen).

\section{Immunohistochemistry}

As both macrophages and mast cells express the CD68 epitope detected with the monoclonal antibody (mAb) KP1, doublelabelling for CD68 and human leukocyte antigen (HLA)-DR was needed to identify macrophages (CD68+HLA-DR+ cells), as mast cells are HLA-DR negative (fig. 1a). Similarly, as macrophages, eosinophils and T-cells may all express CD4, double-staining with CD3 and CD4 was essential to identify CD4+ T-cells (fig. 1b). From a lower lobe biopsy, 4- $\mu \mathrm{m}$ cryosections were prefixed for $10 \mathrm{~min}$ in $1 \%$ paraformaldehyde. Macrophages were identified by a combination of $\mathrm{mAb}$ directed against CD68 (clone KP1, MO814, IgG ${ }_{1}$; DAKO A/S, Glostrup, Denmark) and HLA-DR (clone L123, IgG $2 \mathrm{a}$; Becton Dickinson Immunocytometry Systems, San Jose, CA, USA) followed by an appropriate mixture of fluorochromeconjugated goat anti-mouse IgG-subclass specific reagents, combined with 4',6-diamino-2-phenylindole to visualise the nucleus (all from Molecular Probes, Eugene, OR, USA). T-cells and their subsets were identified by anti-CD3 (clone RIV9, $\mathrm{IgG}_{3}$; Monosan, Am Uden, The Netherlands) combined with anti-CD4 (Leu 3, IgG 1 ; Becton Dickinson), anti-CD8 (clone $\mathrm{DK} 25, \mathrm{IgG}_{1} ; \mathrm{DAKO} \mathrm{A} / \mathrm{S}$ ) or $\mathrm{mAb}$ to the $\delta$ chain of the T-cell receptor (TCR)- $\gamma \delta$ (TCR $\delta 1, \mathrm{IgG}_{1}$; T Cell Sciences, Cambridge, MA, USA), followed by Alexa-conjugated goat anti-mouse IgG subclass specific reagents (Molecular Probes). mAb TCR- $\gamma \delta$ was also combined with anti-CD8 ( $\operatorname{IgG}_{2 b}$; Serotec Ltd., Oxford, UK). Negative controls included omitting primary antibodies and using nonimmune mouse Ig in similar concentrations. A jejunal section from a patient with coeliac disease was used as a positive control for $\gamma \delta$-T-cells. The primary antibodies were incubated for $20 \mathrm{~h}$ at $4{ }^{\circ} \mathrm{C}$ and the secondary antibodies were applied for $1 \mathrm{~h}$ at room temperature.

\section{Quantification of leukocytes}

All slides were coded and analysed using a Zeiss Axioplane2 microscope (Carl Zeiss, Oberkochen, Germany) at $630 \times$ magnification. Positively stained cells were counted in intact epithelium (defined as presence of both basal and columnar cells) and in a subepithelial zone $114 \mu \mathrm{m}$ beneath the reticular basement membrane. Excluding submucosal glands and vessels, all available area was analysed. To gain sufficient tissue to obtain representative cell counts [11], 2-4 sections

\section{TABLE 1 Characteristics of the study population}

\begin{tabular}{|c|c|c|c|c|c|}
\hline & \multicolumn{2}{|c|}{ Asthmatic workers } & \multicolumn{2}{|c|}{ Healthy workers } & \multirow{2}{*}{$\begin{array}{c}\text { Nonexposed controls } \\
\text { Nonsmokers }\end{array}$} \\
\hline & Nonsmokers & Smokers & Nonsmokers & Smokers & \\
\hline Subjects & 8 & 12 & 8 & 7 & 10 \\
\hline Age yrs & $35(27-49)$ & $40(32-59)$ & $36(31-58)$ & $43(32-49)$ & $24(21-44)$ \\
\hline FEV $1 \%$ pred & $91(75-120)$ & $9073-111)$ & $108(90-135)$ & $105(85-124)$ & $112(81-124)$ \\
\hline FEV $_{1} /$ FVC \% & $78(61-82)$ & $67(59-79)$ & 80 (71-87) & 75 (71-84) & $81(74-90)$ \\
\hline Inhaled corticosteroids & $1^{\#}$ & 3 & 0 & 0 & 0 \\
\hline Inhaled $\beta_{2}$-agonist & 4 & 6 & 0 & 0 & 0 \\
\hline
\end{tabular}



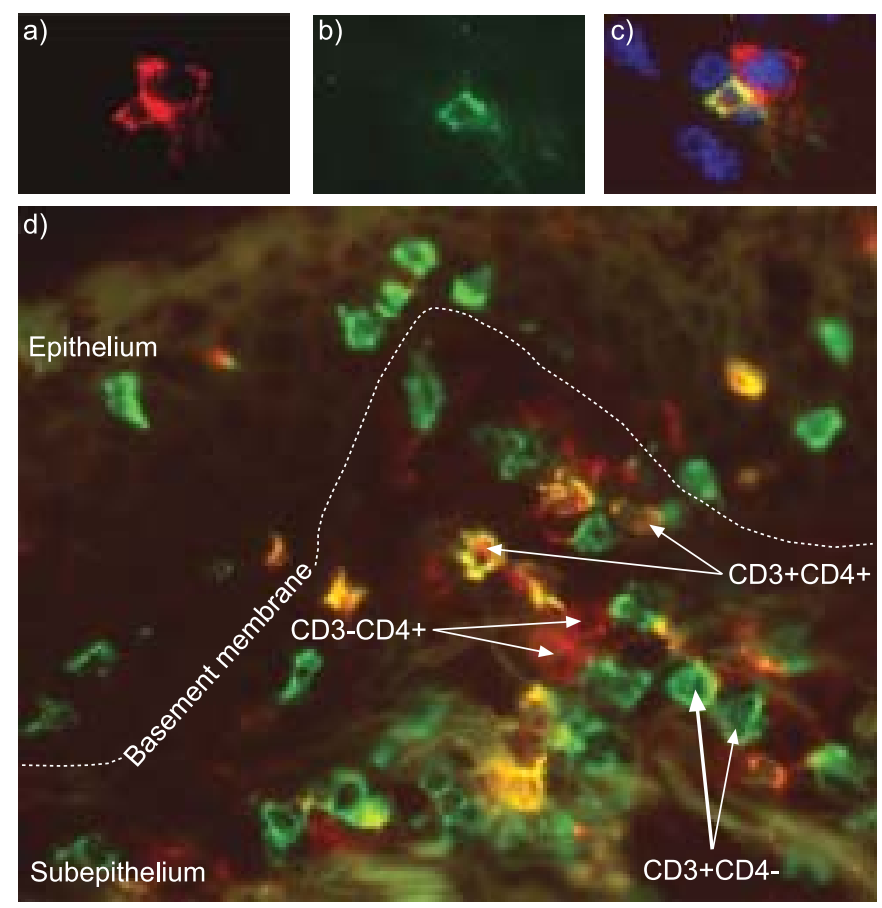

FIGURE 1. a-c): Immunohistofluorescence triple-staining for identification of subepithelial macrophages. a) The monoclonal antibody KP1 to CD68 reacts with mast cells and macrophages, both of which are stained red. b) However, macrophages (but not mast cells) express human leukocyte antigen (HLA)-DR, which is stained green. c) Accordingly, the double-positive cell (CD68+HLA-DR+) represents a macrophage and appears yellow in the overlay image. The CD68+HLA-DR- cell appears red and probably represents a mast cell. In c) the nuclei are visualised blue (4',6-diamino-2-phenylindole). d) Immunohistofluorescence identification of T-cells and T-cell subsets in bronchial mucosa from a nonsmoking asthmatic patient, showing increased density of subepithelial T-cells. The T-cell marker (CD3) is stained green. The CD4+ cells are stained red. The CD3+ (green) T-cells that also express CD4+ (red) appear yellow in this double exposed image (CD3+CD4+ cells). Note that macrophages (CD3-CD4+) appear red, as they do not express the T-cell marker CD3. This particular field contained many CD4- Tcells (CD3+CD4-; green) both in the subepithelium and in the epithelium (i.e. CD8 T-cell subset).

were analysed for each subject and all analysed sections were included. Median (range) 5.7 (1.8-17.2) $\mathrm{mm}$ of intact epithelium and $1.2(0.4-2.8) \mathrm{mm}$ subepithelial area, which corresponded to a basement membrane length of $8.2(2.6-19.8) \mathrm{mm}$ were examined per subject. The final result, expressed as number of intraepithelial cells $\mathrm{mm}^{-1}$ of intact epithelium or number of cells $\cdot \mathrm{mm}^{-2}$ of lamina propria, was calculated as the average of all the measurements performed on each section. In order to directly compare intraepithelial and subepithelial cell numbers and evaluate a possible reallocation of cells between the two compartments, subepithelial leukocytes were also expressed as number of cells $\cdot \mathrm{mm}^{-1}$ of lamina propria. $\gamma \delta$-Tcells were expressed as a percentage of the total number of $\mathrm{T}$ cells (CD3+ cells) counted.

\section{Computer-assisted digital image analysis}

Single-colour images were captured with a MicroMax chargecoupled device digital camera system (Princeton Instruments,
Roper Scientific Inc., Princeton, NJ, USA) at $630 \times$ magnification and AnalySIS software (Soft Imaging System $\mathrm{GmbH}$, Münster, Germany; fig. 1a) or the imaging software package MetaMorph 3.0 (Universal Imaging Corporation, Downingtown, PA, USA; fig. 1b).

\section{Statistics}

Results are presented as median (range). Differences between two groups were compared by Mann-Whitney U-test. Instead of Bonferroni adjustments (which have limited applications in biomedical research [12]), the level of significance was set to $1 \%$ to correct for multiple comparisons. Accordingly, when comparing multiple groups, only $\mathrm{p} \leqslant 0.01$ was considered statistically significant. The nonparametric statistical analysis used in the current study is rather sensitive to low sample size, making it more difficult to achieve statistically significant differences. However, p-values between $0.05-0.01$ have been taken into consideration in order not to exclude real differences that do not reach the significance level owing to the low sample size (type II error). The term "significantly increased" is used for $p$-values $\leqslant 0.01$, while the term "increased or decreased" is used for differences with p-values 0.05-0.01. Multiple linear regression analysis was performed in asthmatics and healthy subjects separately by using exposure, lung function, age and smoking as explanatory variables. Chisquared tests were used to calculate differences in the proportion of $\gamma \delta$-T-cells. Correlation coefficients were calculated using Spearman's rank method.

\section{RESULTS}

\section{Subepithelial cell counts}

Nonsmoking asthmatics had significantly increased T-cell (CD3+) density compared with smoking asthmatics $(\mathrm{p}=0.001)$, but compared with the control groups the increase was smaller $(p=0.04)$. The increase was predominantly made up by rise in the CD4+ T-cell subpopulation, which was significantly increased $(p \leqslant 0.01)$ in nonsmoking asthmatics compared with all groups, while there were no difference in CD8+ T-cell densities (table 2; fig. 2a, b). A corresponding CD4+ T-cell density was not observed in smoking asthmatics, who actually had the lowest density of all groups. If asthmatic ex-smokers and steroid-treated asthmatics were excluded from the analysis, the difference in subepithelial CD4+ T-cells between the two asthmatic groups was still highly significant $(\mathrm{p}<0.001)$. Multiple linear regression analysis using exposure, lung function, age and smoking as explanatory variables confirmed that apart from smoking in the asthmatic group, none of the variables influenced the results.

The macrophage (CD68+HLA-DR+) density was increased in nonsmoking asthmatics compared with nonsmoking exposed and nonexposed controls ( $\mathrm{p}=0.02$ and $\mathrm{p}=0.03$, respectively), but such an increase was not observed in smoking asthmatics (table 2; fig. 2c). Both relocated smoking asthmatics (228 (106407) cells $\cdot \mathrm{mm}^{-2}$ ) and relocated nonsmoking asthmatics (788 (556-989) cells $\cdot \mathrm{mm}^{-2}$ ), had similar subepithelial CD4+ T-cell densities to their corresponding exposed asthmatic colleagues (smoking asthmatics 225 (88-317) cells $\cdot \mathrm{mm}^{-2}$; nonsmoking asthmatics $737(331-1,131)$ cells $\left.\cdot \mathrm{mm}^{-2}\right)$.

No mucosal $\gamma \delta$-T-cells were observed in seven out of the 45 subjects, and the overall amount of $\gamma \delta$-T-cells was too low to 
TABLE 2 Subepithelial leukocyte subsets

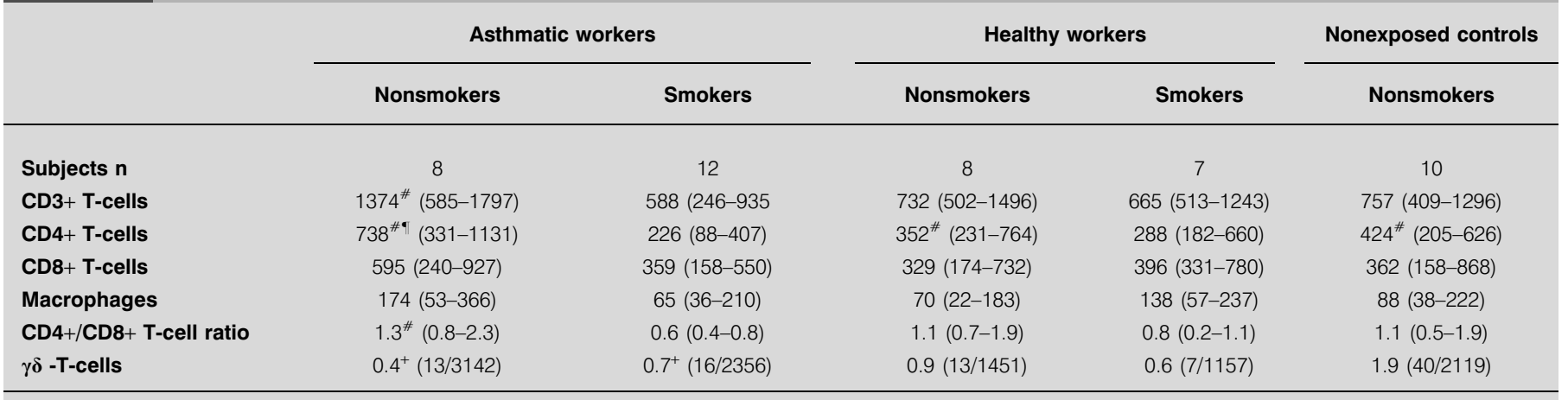

Data for CD3+, CD4+, CD8+ T-cells and macrophages are expressed as median cells $\cdot \mathrm{mm}^{-2}$ (range). $\gamma \delta$-T-cells are expressed as percentage of all subepithelial CD3+ Tcells (grouped cell count) in each group. ${ }^{\#}: p \leqslant 0.01$ versus smoking asthmatics; ${ }^{\varphi}: p \leqslant 0.01$ versus nonsmoking healthy workers, smoking healthy workers and nonexposed controls; ${ }^{+}: p \leqslant 0.01$ versus nonexposed controls.

justify interindividual group evaluation. The individual $\gamma \delta+\mathrm{T}-$ cell and CD3+ T-cell numbers were therefore summarised separately within each of the five groups. Such group-based data showed that the proportion of subepithelial $\gamma \delta$-T-cells was significantly reduced in both smoking and nonsmoking asthmatics compared with the nonexposed controls (Chisquared test; table 2). When all subjects were grouped together, 89 out of 10,225 subepithelial CD3+ T-cells $(0.9 \%)$ expressed $\gamma$ and $\delta$ chains (TCR $\gamma \delta$ ), and double-labelling for TCR $\gamma \delta$ and CD8 revealed that $23 \%$ of these $\gamma \delta$-T-cells coexpressed CD8.

\section{Intraepithelial cell counts}

The number of intraepithelial macrophages and CD8+ Tcells $\cdot \mathrm{mm}^{-1}$ intact epithelium was increased in both asthmatic and healthy smokers compared with their corresponding nonsmoking groups (table 3 ). While intraepithelial CD4+ Tcell counts were significantly increased $(p<0.001)$ in the healthy smokers, no such increase was observed in smoking asthmatics compared with nonsmoking asthmatics (table 3). The proportion of intraepithelial $\gamma \delta$-T-cells was significantly reduced in both smoking and nonsmoking asthmatics $(p<0.001)$ compared with nonexposed controls (table 3). When all subjects were grouped together, 172 out of 6,492 intraepithelial CD3+ T-cells (2.6\%) expressed TCR $\gamma \delta$. Doublelabelling for $\mathrm{TCR} \gamma \delta$ and $\mathrm{CD} 8$ revealed that $53 \%$ of the intraepithelial $\gamma \delta$-T-cells co-expressed CD8.

\section{T-cell distribution}

In order to directly compare intraepithelial and subepithelial T-cell numbers, and evaluate a possible reallocation of cells between the two compartments, subepithelial T-cells were additionally expressed as number of cells $\cdot \mathrm{mm}^{-1}$ of lamina propria. When subepithelial and intraepithelial T-cells were summarised, the number of CD4+ T-cells was still significantly reduced in smoking asthmatics $\left(39(20-70)\right.$ cells $\left.\cdot \mathrm{mm}^{-1}\right)$ compared with nonsmoking asthmatics (108 (50-174) cells $\left.\cdot \mathrm{mm}^{-1} ; \mathrm{p}<0.001\right)$. However, the initial difference in lamina propria CD8+ T-cells between smoking and nonsmoking asthmatics was no longer significant $\left(75(47-128)\right.$ cells $\cdot \mathrm{mm}^{-1}$ in smoking asthmatics versus 94 (41-149) cells $\cdot \mathrm{mm}^{-1}$ in nonsmoking asthmatics).

\section{Correlation}

FEV1 was positively correlated to the subepithelial T-cell $(\mathrm{CD} 3+)$ density $(\mathrm{r}=0.69, \mathrm{p}=0.01)$ in smoking asthmatics, with similar contribution from the CD4+ (fig. 3) and CD8+ T-cell subsets, as both were correlated equally to FEV1 (both $r=0.57$, $\mathrm{p}=0.05)$. No such correlation was found in nonsmoking asthmatics or in the control groups.

\section{DISCUSSION}

The present increase in subepithelial CD4+ T-cell density in nonsmokers with occupational asthma is comparable to what has previously been shown in "traditional" asthma [1, 2], and illustrates the immunopathological similarity between occupational and nonoccupational asthma [13, 14]. The lack of a similar increase in subepithelial CD4+ T-cell density in the smoking asthmatics was rather surprising, and apparently disagrees with the current concept of asthma immunopathology. There are no other comparable human studies of bronchial inflammation in smoking asthmatics, except a previous report by the current authors of inhibited increase of total leukocytes (CD45+ cells) and eosinophils in smokers with occupational asthma [7]. The current results identify the CD4+ T-cells as the major leukocyte subgroup responsible for the reduction in CD45+ cells in smoking asthmatics. As CD4+ $\mathrm{T}$-cells were reduced to a greater extent than CD8+ T-cells, the CD4+/CD8+ T-cell ratio was reduced in smoking asthmatics.

In general, cigarette smoking seems to induce a bronchial inflammatory reaction, even in asymptomatic subjects $[15,16]$. Increased bronchial CD8+ T-cell and macrophage density and reduced subepithelial CD4/CD8 ratio are consistent findings in smokers $[17,18]$, a phenomenon which was also observed in the current healthy smokers. Thus, a smoking-induced inhibited increase in subepithelial CD4+ T-cell density in asthmatics appears to disagree with the generally accepted hypothesis that smoking amplifies asthmatic airway inflammation [19]. The present smoking asthmatics do not resemble chronic obstructive pulmonary disease (COPD) patients, as they all had history, symptoms and reversible airflow obstruction consistent with asthma and not COPD. Moreover, the bronchial cell infiltrate in these smoking asthmatics differed markedly from that in COPD patients as 

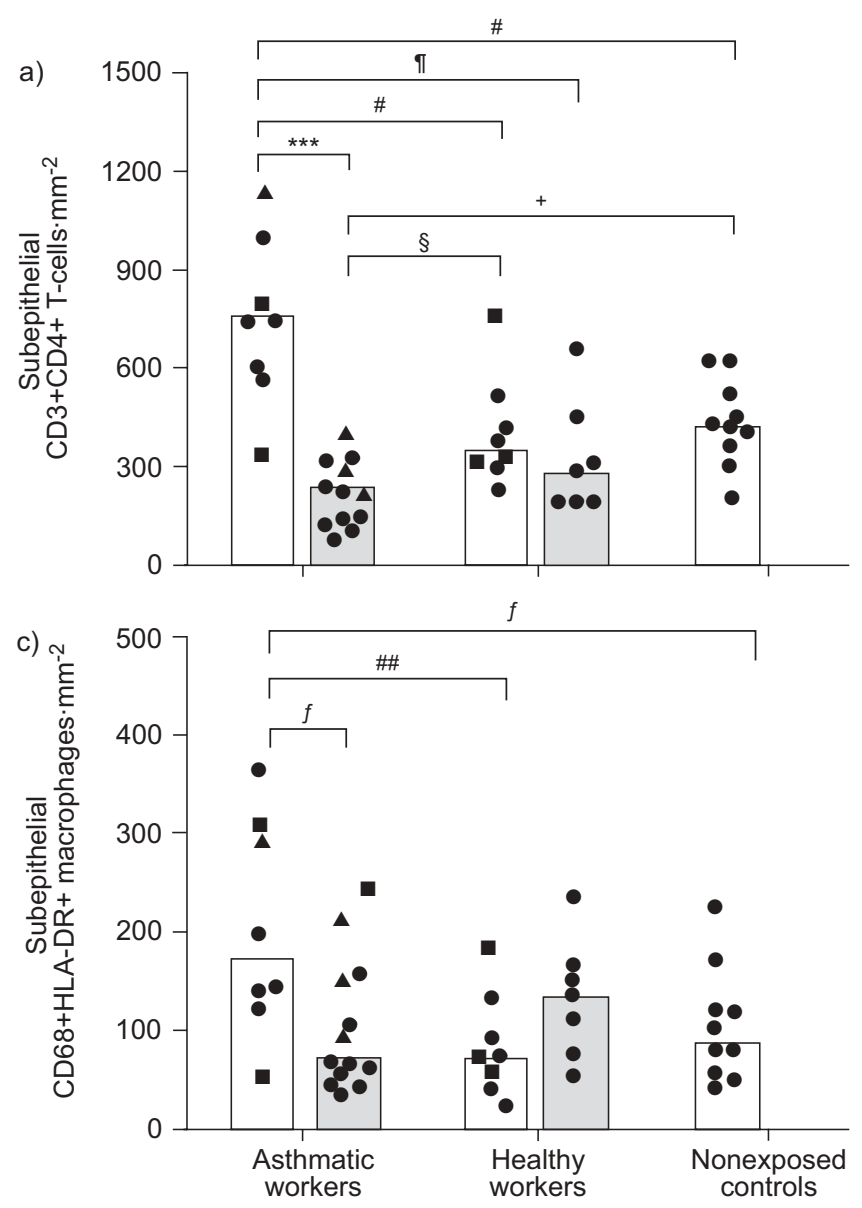

they had no increase in subepithelial macrophages or CD8+ Tcells as previously reported in COPD [20, 21].

The majority of T-cells express the $\alpha$ and $\beta$ chains of the TCR, while a small fraction $(\sim 5 \%)$ expresses the $\gamma$ and $\delta$ chains $(\gamma \delta$ T-cells). The function of $\gamma \delta$-T-cells in normal and asthmatic airways is still unknown, and they predominantly localise to mucosal surfaces. It is debated whether $\gamma \delta$-T-cells protect the bronchial mucosa or promote airway inflammation [22]. While increased $\gamma \delta$-T-cell counts have been reported in bronchoalveolar lavage [23] and induced sputum from asthmatics with acute exacerbations [24], other studies report no difference between asthmatic and control subjects in bronchial biopsies [25] and bronchoalveolar lavage [22, 26]. The current observation of depleted intraepithelial $\gamma \delta$-T-cell levels in asthmatics supports the theory that these cells are involved in maintaining mucosal homeostasis.

Both smoking asthmatics and healthy smokers had increased numbers of intraepithelial macrophages and CD8+ T-cells, but in contrast to healthy smokers, there was no increase in intraepithelial CD4+ T-cells in smoking asthmatics. Thus, smoking may predominantly affect CD4+ T-cell recruitment. Whereas decreased subepithelial CD8+ T-cell density in smoking asthmatics could partly be explained by migration from the lamina propria to the epithelium, intraepithelial migration could not explain the reduced CD4+ Tcell density.

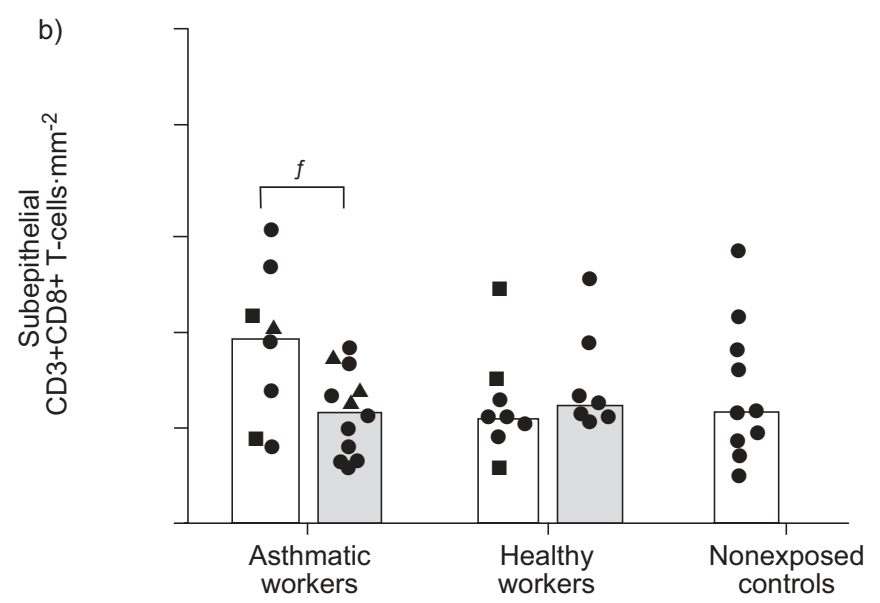

FIGURE 2. Individual subepithelial cell density (cells $\cdot \mathrm{mm}^{-2}$ ) of a) $\mathrm{CD} 4+\mathrm{T}$ cells, b) CD8+ T-cells and c) macrophages in nonsmoking ( $\square$ ) and smoking ( $\square$ ) asthmatic workers, healthy workers and nonexposed controls. The bars represent median values. $\mathbf{\Delta}$ : treatment with inhaled corticosteroids; $\mathbf{\square}$ : ex-smokers; other individuals. HLA-DR: human leukocyte antigen-DR. ${ }^{\#}: p=0.01 ;{ }^{\bullet}: p=0.004$; ${ }^{+}: p=0.001 ;{ }^{\varsigma}: p=0.005 ;{ }^{f}: p=0.03 ;{ }^{\# \#}: p=0.02 ;{ }^{* *}: p<0.001$.

Smoking may have profound immunosuppressive effects, as shown by the smoking-induced inhibition of pulmonary T-cell responses in mice [27, 28] and humans [29]. Although shortterm smoke exposure may induce airway inflammation in murine asthma models [30], more chronic antigen stimulation and smoke exposure may actually inhibit an asthma-induced airway influx of macrophages, CD4+ T-cells and eosinophils [31] as well as dendritic cells [32]. Moreover, tobacco smoke prevented the activation and expansion of pulmonary CD4+ T-cells in a murine adenovirus infection model [32]. Thus, smoking may modify airway inflammation in a dosedependent and time-related manner. Interestingly, one third of smoking asthmatics reported worsening of their asthmatic symptoms after smoking cessation [33]. It is, however, rather challenging to explain why subepithelial CD4+ and CD8+ T-cell density correlated to FEV1 in smoking asthmatics, while no such correlation was found in nonsmoking asthmatics or in the control groups.

A rather limited number of subjects was included in the present study, a weakness shared with many published bronchial biopsy studies. However, the lack of an asthmaassociated increase in subepithelial CD4+ T-cells in smokers was observed in a group of 12 patients and compared with a smaller group of nonsmoking asthmatics $(n=8)$, where the expected increase in subepithelial CD4+ T-cells was observed. The difference between the two asthmatic groups was highly significant when nonparametric statistics that are sensitive to 
TABLE 3 Intraepithelial leukocyte subsets

\begin{tabular}{|c|c|c|c|c|c|}
\hline & \multicolumn{2}{|c|}{ Asthmatic workers } & \multicolumn{2}{|c|}{ Healthy workers } & \multirow{2}{*}{$\begin{array}{c}\text { Nonexposed controls } \\
\text { Nonsmokers }\end{array}$} \\
\hline & Nonsmokers & Smokers & Nonsmokers & Smokers & \\
\hline Subjects $n$ & 8 & 12 & 8 & 7 & 10 \\
\hline CD3+ T-cells & $15^{\#}(7-34)$ & $33(19-74)$ & $9^{\bullet}(6-29)$ & $32(22-50)$ & $26(8-30)$ \\
\hline CD4+ T-cells & $5(0-16)$ & $8(2-17)$ & $2^{*}(1-4)$ & $8(5-16)$ & $6(3-7)$ \\
\hline CD4+/CD8+ T-cell ratio & $0.4(0.0-1.2)$ & $0.3(0.1-0.7)$ & $0.1(0.0-1.1)$ & $0.4(0.2-0.7)$ & $0.4(0.1-0.8)$ \\
\hline$\gamma \delta$-T-cells & $2.5^{+}(23 / 925)$ & $1.7^{+}(57 / 3357)$ & $4.1(19 / 467)$ & $3.3(30 / 916)$ & $5.3(43 / 812)$ \\
\hline
\end{tabular}

Data for CD3+, CD4+, CD8+ T-cells and macrophages are expressed as median (range) cells $\cdot \mathrm{mm}^{-1}$ epithelium. $\gamma \delta$-T-cells are expressed as percentage of all intraepithelial CD3+ T-cells (grouped count number) in each group. ${ }^{*}: p \leqslant 0.01$ versus smoking asthmatics; ${ }^{\natural}: p \leqslant 0.01$ versus smoking healthy workers; ${ }^{+}: p \leqslant 0.01$ versus nonexposed controls

small samples were used. The difference could not be ascribed to the inclusion of ex-smokers or steroid treated patients, as excluding these subjects did not change the statistical differences.

The study was performed in subjects with occupational asthma who had been exposed to aluminium potroom fume emissions. Although it can be argued that the decrease in bronchial CD4+ T-cells in smoking asthmatics was due to occupational exposure in combination with smoking, there was no difference in the CD4+ T-cell density between smoking and nonsmoking healthy workers who were all exposed to the same working environment as the asthmatics. Moreover, seven of the smoking asthmatics had been relocated to unexposed environments for median 2 yrs prior to examination. These relocated smoking asthmatics had similar CD4+ T-cell densities to the smoking asthmatics who were still exposed.

Although the smoking-induced lack of increase in bronchial CD4+ T-cells was observed in asthmatics in an occupational

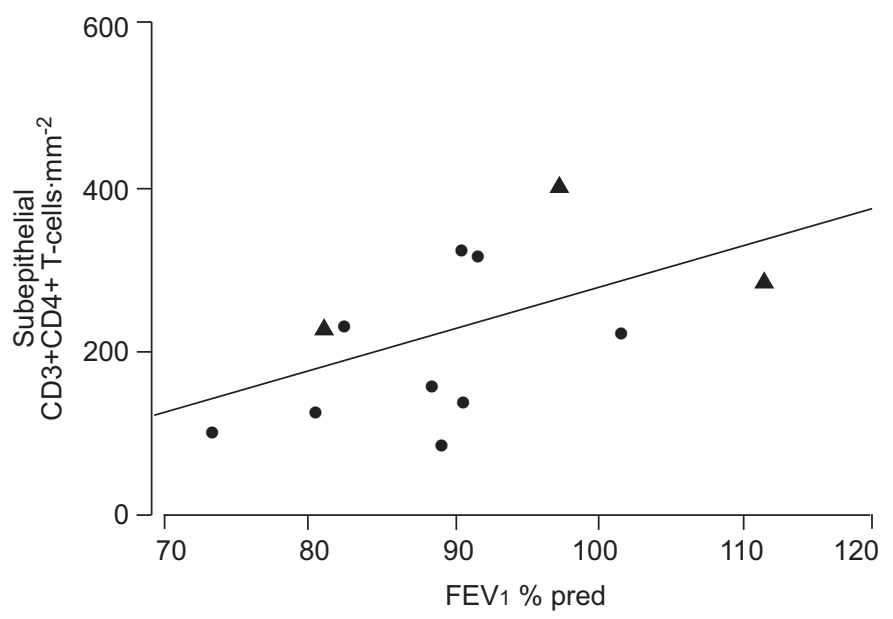

FIGURE 3. The subepithelial density of CD4+ T-cells was positively correlated to forced expiratory volume in one second (FEV1) \% predicted (\% pred) value in smoking asthmatics. $r=0.57 ; p=0.05$. $\mathbf{\Delta}$ : treatment with inhaled corticosteroids; - : other individuals. setting, this phenomenon may not be restricted to occupational asthma. Rather, smoking asthmatics may represent a separate asthmatic phenotype without the characteristic asthma-associated increase in bronchial CD4+ T-cells, which challenges the current understanding of the pathogenetic mechanisms in asthma.

\section{ACKNOWLEDGEMENTS}

The authors would like to thank all the workers for participating in the study.

\section{REFERENCES}

1 Bousquet J, Jeffery PK, Busse WW, Johnson M, Vignola AM. Asthma. From bronchoconstriction to airways inflammation and remodeling. Am J Respir Crit Care Med 2000; 161: 1720-1745.

2 Eapen SS, Busse WW. Asthma. Clin Allergy Immunol 2002; 16: 325-353.

3 Humbert M, Menz G, Ying S, et al. The immunopathology of extrinsic (atopic) and intrinsic (non-atopic) asthma: more similarities than differences. Immunol Today 1999; 20: 528-533.

4 Karjalainen EM, Lindqvist A, Laitinen LA, et al. Airway inflammation and basement membrane tenascin in newly diagnosed atopic and nonatopic asthma. Respir Med 2003; 97: 1045-1051.

5 Mapp CE, Boschetto P, Maestrelli P, Fabbri LM. Occupational Asthma. Am J Respir Crit Care Med 2005; 172: 280-305.

6 Thomson NC, Chaudhuri R, Livingston E. Asthma and cigarette smoking. Eur Respir J 2004; 24: 822-833.

7 Sjaheim T, Halstensen TS, Lund MB, et al. Airway inflammation in aluminium potroom asthma. Occup Environ Med 2004; 61: 779-785.

8 Kongerud J, Boe J, Søyseth V, Naalsund A, Magnus P. Aluminium potroom asthma: the Norwegian experience. Eur Respir J 1994; 7: 165-172.

9 International consensus report on diagnosis and treatment of asthma. National Heart, Lung and Blood Institute, National Institutes of Health. Bethesda, Maryland 20892. 
Publication no. 92-3091, March 1992. Eur Respir J 1992; 5: 601-641.

10 Abramson MJ, Wlodarczyk JH, Saunders NA, Hensley MJ. Does aluminum smelting cause lung disease? Am Rev Respir Dis 1989; 139: 1042-1057.

11 Sullivan P, Stephens D, Ansari T, Costello J, Jeffery P. Variation in the measurements of basement membrane thickness and inflammatory cell number in bronchial biopsies. Eur Respir J 1998; 12: 811-815.

12 Perneger TV. What's wrong with Bonferroni adjustments. BMJ 1998; 316: 1236-1238.

13 Frew AJ, Chan H, Lam S, Chan-Yeung M. Bronchial inflammation in occupational asthma due to western red cedar. Am J Respir Crit Care Med 1995; 151: 340-344.

14 Mapp CE, Saetta M, Maestrelli P, et al. Mechanisms and pathology of occupational asthma. Eur Respir J 1994; 7: 544554.

15 Amin K, Ekberg-Jansson A, Lofdahl CG, Venge P. Relationship between inflammatory cells and structural changes in the lungs of asymptomatic and never smokers: a biopsy study. Thorax 2003; 58: 135-142.

16 Cosio MG, Majo J, Cosio MG. Inflammation of the airways and lung parenchyma in COPD: role of T cells. Chest 2002; 121: Suppl. 5, 160S-165S.

17 Di Stefano A, Caramori G, Ricciardolo FL, Capelli A, Adcock IM, Donner CF. Cellular and molecular mechanisms in chronic obstructive pulmonary disease: an overview. Clin Exp Allergy 2004; 34: 1156-1167.

18 Saetta M, Turato G, Maestrelli P, Mapp CE, Fabbri LM. Cellular and structural bases of chronic obstructive pulmonary disease. Am J Respir Crit Care Med 2001; 163: 1304-1309.

19 Floreani AA, Rennard SI. The role of cigarette smoke in the pathogenesis of asthma and as a trigger for acute symptoms. Curr Opin Pulm Med 1999; 5: 38-46.

20 Saetta M, Turato G. Airway pathology in asthma. Eur Respir J 2001; 18: Suppl. 34, 18s-23s.

21 Sutherland ER, Martin RJ. Airway inflammation in chronic obstructive pulmonary disease: comparisons with asthma. J Allergy Clin Immunol 2003; 112: 819-827.
22 Krug N, Erpenbeck VJ, Balke K, et al. Cytokine profile of bronchoalveolar lavage-derived $\mathrm{CD}^{+}, \mathrm{CD}^{+}$, and $\gamma \delta \mathrm{T}$ cells in people with asthma after segmental allergen challenge. Am J Respir Cell Mol Biol 2001; 25: 125-131.

23 Spinozzi F, Agea E, Bistoni $\mathrm{O}$, et al. Increased allergenspecific, steroid-sensitive $\gamma \delta \mathrm{T}$ cells in bronchoalveolar lavage fluid from patients with asthma. Ann Intern Med 1996; 124: 223-227.

24 Hamzaoui A, Kahan A, Ayed K, Hamzaoui K. T cells expressing the $\gamma \delta$ receptor are essential for Th2-mediated inflammation in patients with acute exacerbation of asthma. Mediators Inflamm 2002; 11: 113-119.

25 Fajac I, Roisman GL, Lacronique J, Polla BS, Dusser DJ. Bronchial $\gamma \delta$ T-lymphocytes and expression of heat shock proteins in mild asthma. Eur Respir J 1997; 10: 633-638.

26 Walker C, Kaegi MK, Braun P, Blaser K. Activated T cells and eosinophilia in bronchoalveolar lavages from subjects with asthma correlated with disease severity. J Allergy Clin Immunol 1991; 88: 935-942.

27 Holt PG. Immune and inflammatory function in cigarette smokers. Thorax 1987; 42: 241-249.

28 Lambert C, McCue J, Portas M, et al. Acrolein in cigarette smoke inhibits T-cell responses. J Allergy Clin Immunol 2005; 116: 916-922.

29 Pyatt DW, Stillman WS, Irons RD. Hydroquinone, a reactive metabolite of benzene, inhibits NF-kappa B in primary human CD4+ $\mathrm{T}$ lymphocytes. Toxicol Appl Pharmacol 1998; 149: 178-184.

30 Moerloose KB, Pauwels RA, Joos GF. Short-term cigarette smoke exposure enhances allergic airway inflammation in mice. Am J Respir Crit Care Med 2005; 172: 168-172.

31 Melgert BN, Postma DS, Geerlings M, et al. Short-term smoke exposure attenuates ovalbumin-induced airway inflammation in allergic mice. Am J Respir Cell Mol Biol 2004; 30: 880-885.

32 Robbins CS, Dawe DE, Goncharova SI, et al. Cigarette smoke decreases pulmonary dendritic cells and impacts antiviral immune responsiveness. Am J Respir Cell Mol Biol 2004; 30: 202-211.

33 Hillerdahl G, Rylander R. Asthma and cessation of smoking. Clin Allergy 1984; 14: 45-47. 